\title{
The Updated Brazilian National Air Quality Standards: A Critical Review
}

\author{
Bruno Siciliano, ${ }^{a}$ Guilherme Dantas, ${ }^{a}$ Cleyton M. da Silva ${ }^{a, b}$ and Graciela Arbilla ${ }^{\circledR *, a}$ \\ anstituto de Química, Universidade Federal do Rio de Janeiro, Centro de Tecnologia, Bloco A, \\ Cidade Universitária, Ilha do Fundão, 21949-900 Rio de Janeiro-RJ, Brazil \\ ${ }^{b}$ Engenharia Ambiental, Universidade Veiga de Almeida, \\ Campus de Maracanã, 20271-020 Rio de Janeiro-RJ, Brazil
}

\begin{abstract}
On November 19, 2018, 30 years after establishment, the updated Brazilian National Air Quality Standards (NAQS) were published. These NAQS were formulated as a fundamental part and instrument of the National Program for the Control of Air Quality and considering, as a reference, the World Health Organization Air Quality Guidelines, published in 2005. An important contribution is the inclusion of $\mathrm{PM}_{2.5}$ (particulate matter with an aerodynamic diameter less than $2.5 \mu \mathrm{m}$ ) as a criteria pollutant and a more restrictive target limit for $\mathrm{PM}_{10}$ (particles that have aerodynamic diameters less than or equal to $10 \mu \mathrm{m}$ ). In this work, the NAQS were discussed using, as a case study, data collected during the 2016 Olympic and Paralympic Games. The lack of $\mathrm{PM}_{2.5}$ data for Brazilian cities results in the calculation of a lower air quality index (AQI), leading to ostensibly good air quality. The results presented in this study clearly support the requirement of improvement of the new resolution since, in the present form, it does not meet the main goal of protecting public health.
\end{abstract}

Keywords: air quality standards, air quality index, air monitoring, CONAMA

\section{Introduction}

According to a recent World Health Organization (WHO) report, ${ }^{1} 4.2$ million deaths per year can be attributed to ambient air pollution due to stroke, ischemic heart disease, lung cancer and chronic obstructive pulmonary disease. Developed and developing countries are affected alike, while low- and moderate-income (LMI) countries experience the highest burden (nearly 90\%), mainly in the western Pacific and Southeast Asia regions. ${ }^{1}$

In $2016, \mathrm{WHO}^{2}$ released a new model that uses data from satellite and ground stations to estimate population exposure to particulate matter with an aerodynamic diameter less than $2.5 \mu \mathrm{m}\left(\mathrm{PM}_{2.5}\right)$. Data for $\mathrm{PM}_{10}$ (particles that have aerodynamic diameters less than or equal to $10 \mu \mathrm{m})$ and $\mathrm{PM}_{2.5}$ were also compiled for approximately 3000 cities and districts. The model confirmed that $92 \%$ of the world population lives in places where air quality levels exceed World Health Organization Air Quality Guidelines (WHO AQGs) for $\mathrm{PM}_{2.5}\left(10 \mu \mathrm{g} \mathrm{m}^{-3}\right.$ annual mean). ${ }^{2}$

Data from 45 Brazilian stations were included in the WHO database, collected in 2014. ${ }^{3}$ For $\mathrm{PM}_{2.5}$ concentrations, the mean annual value (for the 45 stations)

*e-mail: gracielaiq@gmail.com was $15 \mu \mathrm{g} \mathrm{m}^{-3}$, while only 4 stations reported mean annual values lower than $10 \mu \mathrm{g} \mathrm{m}^{-3}$. For $\mathrm{PM}_{10}$, the mean annual value for all the stations was $34 \mu \mathrm{g} \mathrm{m}^{-3}$, and additionally, 4 stations reported values lower than the WHO guideline $\left(20 \mu \mathrm{g} \mathrm{m}^{-3}\right)$. For 3 stations located in São Paulo State, the mean annual value was also higher than the national standard of $50 \mu \mathrm{g} \mathrm{m}^{-3} .3,4$

The task of reducing pollutant levels is very complex and includes assessing organic and inorganic toxic compounds and if exposure levels are hazardous to human health, may also affect plants, animals and soil and can influence the structure and function of ecosystems and the quality of life. As recommended by WHO, a guideline is defined as any kind of guidance on the protection of human beings or environmental receptors from the adverse effects of air pollutants, while a guideline value is a concentration or a deposition level (i.e., a numerical value) that is linked to an averaging time below which no adverse health effects are expected. Guidelines and guideline values recommended by $\mathrm{WHO}^{5}$ aim to provide a basis for protecting public health and to reduce to a minimum those contaminants that are known or likely to be hazardous to human health. Air quality standards (AQS) are considered the level of any air pollutant that is adopted by a regulatory authority as enforceable and should include the measurement method, 
the statistics used to derive the value to be compared with the standard, the averaging time (hourly, annually, etc.) and the permitted number of exceedances.

In Brazil, the first national air quality standards (NAQS) were established by the National Council for the Environment of the Ministry of the Environment (Conselho Nacional do Meio Ambiente, CONAMA, of Ministério do Meio Ambiente) in 1990.4,6 These standards represented an important contribution to air quality management, but increases in urban population, industrial and vehicular emissions and scientific evidence about the effect of air pollution on health and climate clearly showed the need for a revision of the NAQS. ${ }^{7}$ On November 19, 2018, after 30 years, CONAMA published Resolution Number $491,{ }^{8}$ which establishes the new NAQS. These new NAQS were formulated as a fundamental part and as instruments of the National Program for the Control of Air Quality (Programa Nacional de Controle da Qualidade do Ar, PRONAR) and considered, as a reference, the WHO AQGs published in 2005. ${ }^{9}$

The main goal of this work is to discuss the new values considering the WHO AQGs and the air quality standards for other countries and to analyze the impact of the new NAQS on air pollution control. Additionally, as a base case, data obtained during the 2016 Olympic and Paralympic Games, which have been previously discussed, ${ }^{10}$ are revisited using the new NAQS.

\section{Experimental}

\section{Analysis of WHO air quality guidelines}

The WHO air quality guidelines were first produced in 1987 (air quality guidelines for Europe) and updated in $1997 . .^{9}$ In 2005 , a new report summarizing the accumulated scientific evidence regarding the health effects of air pollution was released, and guideline values were recommended for four air pollutants: particulate matter (PM), ozone $\left(\mathrm{O}_{3}\right)$, nitrogen dioxide $\left(\mathrm{NO}_{2}\right)$ and sulfur dioxide $\left(\mathrm{SO}_{2}\right)$. These values were designed to offer guidance for reducing the health impacts of air pollution across all WHO regions and were developed to support actions in improving air quality to protect public health in different contexts worldwide. In addition to guideline values, interim targets were proposed for each pollutant as incremental steps in a progressive reduction of air pollution, but progress toward guideline values is considered the ultimate objective of air quality control in all WHO areas. ${ }^{9}$ The WHO proposed values are presented in Table 1.

In 2015, WHO organized a global consultation meeting to discuss the latest available evidence on the health effects of several ambient air pollutants, and the results were compiled in a report that would contribute to future updates of the AQGs. ${ }^{11}$ Considering the previous editions of the WHO ambient AQGs, 32 air pollutants were selected, including the so-called classical pollutants $\left(\mathrm{PM}, \mathrm{O}_{3}, \mathrm{NO}_{2}\right.$ and $\mathrm{SO}_{2}$ ) and organic and inorganic compounds, and were categorized in four groups, as shown in Table 2, to reflect the need for systematic review of evidence in the context of the process of updating the existing AQGs. ${ }^{11}$

Pollutants included in group 1 are those considered of greatest importance in the process of updating the WHO AQGs due to the large body of new evidence regarding adverse health effects. For these pollutants, their systematic re-evaluation was recommended as well as consideration of interactions among pollutants and modeling results. For pollutants in group 2, a systematic revision was also recommended due to their widespread presence in ambient

Table 1. WHO air quality guidelines and interim targets proposed in $2005^{9}$

\begin{tabular}{|c|c|c|c|c|c|}
\hline \multirow{2}{*}{ Pollutant } & \multirow{2}{*}{ Averaging time } & \multicolumn{4}{|c|}{ Mean concentration / $\left(\mu \mathrm{g} \mathrm{m}^{-3}\right)$} \\
\hline & & IT-1 & IT-2 & IT-3 & AQG \\
\hline \multirow{2}{*}{$\mathrm{PM}_{10}$} & annual mean & 70 & 50 & 30 & 20 \\
\hline & 24-hour mean & 150 & 100 & 75 & 50 \\
\hline \multirow{2}{*}{$\mathrm{PM}_{2.5}$} & annual mean & 35 & 25 & 15 & 10 \\
\hline & 24-hour mean & 75 & 50 & 37.5 & 25 \\
\hline $\mathrm{O}_{3}$ & 8-hour mean & 160 & - & - & 100 \\
\hline \multirow{2}{*}{$\mathrm{NO}_{2}$} & annual mean & - & - & - & 40 \\
\hline & 1-hour mean & - & - & - & 200 \\
\hline \multirow{2}{*}{$\mathrm{SO}_{2}$} & 24-hour mean & 125 & 50 & - & 20 \\
\hline & 10-min mean & - & - & - & 500 \\
\hline
\end{tabular}

IT-1: interim target 1; IT-2: interim target 2; IT-3: interim target 3; AQG: target value (Air Quality Guideline); PM $_{10}$ : particles that have aerodynamic diameters less than or equal to $10 \mu \mathrm{m} ; \mathrm{PM}_{2.5}$ : particulate matter with an aerodynamic diameter less than $2.5 \mu \mathrm{m}$. 
Table 2. Classification of air pollutants considering the WHO expert pollutant advice ${ }^{11}$

\begin{tabular}{lccc}
\hline Group 1 & Group 2 & Group 3 & Group 4 \\
\hline Particulate matter & cadmium & arsenic & mercury \\
Ozone & chromium & manganese & asbestos \\
Nitrogen dioxide & lead & platinum & formaldehyde \\
Sulfur dioxide & benzene & vanadium & styrene \\
Carbon monoxide & PCDDs and PCDFs & butadiene & tetrachloroethylene \\
& PAHs & carbon disulfide & fluoride \\
& & trichloroethylene & PCBs \\
& & acrylonitrile & hydrogen sulfide \\
& & vinyl chloride & dichloromethane
\end{tabular}

aAHs were assigned to group 2 taking benzo[ $a$ ]pyrene as a reference compound; bacrylonitrile was classified in group 3 with possible reclassification to group 2. PCDDs: polychlorinated dibenzodioxins; PCDFs: polychlorinated dibenzofurans; PAHs: polycyclic aromatic hydrocarbons; PCBs: polychlorinated biphenyls.

air and the new evidence about adverse health effects. A revision of AQGs for pollutants included in group 3 was also recommended, although with less urgency than for pollutants included in the two previous groups. For pollutants included in group 4, recent evidence does not justify the imminent need for revision regarding ambient air pollution, but these pollutants are currently considered in occupational guidelines, water guidelines and other types of management processes.

\section{Analysis of Brazilian national air quality standards}

National air quality standards are set by each country to protect the public health of their citizens and are an important component of national environmental policies. ${ }^{9}$ The new Brazilian NAQS ${ }^{8}$ are presented in Table 3. For comparison, values determined in $1990^{4}$ are also indicated. Following the WHO recommendations, in addition to the NAQS, interim targets were proposed for each pollutant as incremental steps in a progressive reduction of air pollution down to the final proposed value. Interim target (IT) values for IT-1 should be adopted immediately, except for $\mathrm{CO}, \mathrm{Pb}$ and total particulate matter (TPM) for which NAQS should be adopted. NAQS values for the classical air pollutants are those recommended by WHO in 2005. ${ }^{9}$ According to the new legislation, there is no predetermined data to adopt for each interim target nor final NAQS values for $\mathrm{PM}_{2.5}$, $\mathrm{PM}_{10}, \mathrm{O}_{3}, \mathrm{NO}_{2}$ and $\mathrm{SO}_{2}$, and the environmental agencies of each state and the Federal District should elaborate a plan to control pollutant emissions, considering the individual emission sources, geographical characteristics and the national standards.
The new resolution also establishes that the Ministry of the Environment and the environmental agencies of each state and the Federal District should establish a guide with reference methods to determine pollutant concentrations and calculate the air quality indexes (AQI) using the main six pollutants $\left(\mathrm{PM}_{2.5}, \mathrm{PM}_{10}, \mathrm{O}_{3}, \mathrm{NO}_{2}, \mathrm{SO}_{2}\right.$ and $\left.\mathrm{CO}\right)$. The new resolution only determines the top limit for the first level, which corresponds to good air quality, and is equal to the NAQS (target value). Notably, $\mathrm{PM}_{2.5}$ was not a criteria pollutant in the 1990 CONAMA legislation. ${ }^{4}$ Regarding $\mathrm{O}_{3}$, the averaging time, which was $1 \mathrm{~h}$ (with the value $160 \mu \mathrm{g} \mathrm{m}^{-3}$ that should not be exceeded more than once per year), was increased in the 2018 resolution to $8 \mathrm{~h}$. The consequences of these modifications will be discussed in the Results and Discussion section.

The same interim targets and AQS for $\mathrm{PM}_{2.5}, \mathrm{PM}_{10}, \mathrm{O}_{3}$, $\mathrm{NO}_{2}$ and CO were established in São Paulo State in 2013, whereas the IT- 1 values have been valid since 2013.12 For $\mathrm{SO}_{2}$, the annual mean is the same as that shown in Table 3, but the 24-hour means are 60, 40, 30 and $20 \mu \mathrm{g} \mathrm{m}^{-3}$ for the IT-1, IT-2, IT-3 and final NAQS, respectively. To comparatively assess the degree of air pollution, an $\mathrm{AQI}$ system has been proposed by the São Paulo State Environmental Agency (CETESB) ${ }^{12}$ and is calculated using the combined concentrations of $\mathrm{PM}_{2.5}, \mathrm{PM}_{10}, \mathrm{SO}_{2}$, $\mathrm{CO}$, ozone and $\mathrm{NO}_{2}$. The index used by CETESB since 2013 has a five-level scale, from good air quality (0-40) to extremely high pollution (>200). Between 41 and 80, the air quality is considered "Moderate", a level at which the population is not considered to be affected, except for a reduced number of people. For an AQI in the interval of 81-120, the air quality is considered "Unhealthy" if at 
Table 3. Brazilian NAQS and interim targets determined in $2018 .{ }^{8}$ Values determined in 1990 are also indicated ${ }^{4}$

\begin{tabular}{|c|c|c|c|c|c|c|}
\hline \multirow{2}{*}{ Pollutant } & \multirow{2}{*}{ Averaging time } & \multicolumn{5}{|c|}{ Mean concentration / $\left(\mu \mathrm{g} \mathrm{m}^{-3}\right)$} \\
\hline & & $1990 \mathrm{NAQS}^{4}$ & IT- $1^{8}$ & IT- $2^{8}$ & IT- $3^{8}$ & $2018 \mathrm{NAQS}^{8}$ \\
\hline \multirow{2}{*}{$\mathrm{PM}_{10}$} & annual mean & 50 & 40 & 35 & 30 & 20 \\
\hline & 24-hour mean & 150 & 120 & 100 & 75 & 50 \\
\hline \multirow{2}{*}{$\mathrm{PM}_{2.5}$} & annual mean & - & 20 & 17 & 15 & 10 \\
\hline & 24-hour mean & - & 60 & 50 & 37 & 25 \\
\hline \multirow{2}{*}{$\mathrm{O}_{3}$} & 8-hour mean & - & 140 & 130 & 120 & 100 \\
\hline & 1-hour mean & $160^{\mathrm{a}}$ & - & - & - & - \\
\hline \multirow{2}{*}{$\mathrm{NO}_{2}$} & annual mean & $100^{\mathrm{a}}$ & 60 & 50 & 45 & 40 \\
\hline & 1-hour mean & $320^{\mathrm{a}}$ & 260 & 240 & 220 & 200 \\
\hline \multirow{2}{*}{$\mathrm{SO}_{2}$} & 24-hour mean & $365^{\mathrm{a}}$ & 125 & 50 & 30 & 20 \\
\hline & annual mean & 80 & 40 & 30 & 20 & - \\
\hline $\mathrm{CO}$ & 8-hour mean & 9 & - & - & - & $9^{\mathrm{b}}$ \\
\hline $\mathrm{Pb}^{\mathrm{c}}$ & annual mean & & - & - & - & 0.5 \\
\hline TPM & 24-hour mean & 240 & - & - & - & 240 \\
\hline
\end{tabular}

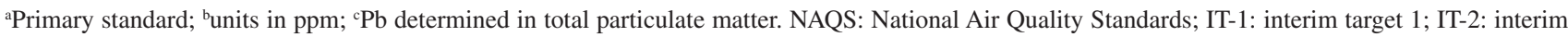
target 2; IT-3: interim target 3; $\mathrm{PM}_{10}$ : particles that have aerodynamic diameters less than or equal to $10 \mu \mathrm{m} ; \mathrm{PM}_{2.5}$ : particulate matter with an aerodynamic diameter less than $2.5 \mu \mathrm{m}$; annual mean: arithmetic annual mean; 1-hour mean: arithmetic 1-hour mean; 8-hour mean: maximum 8-hour mean obtained during the day; 24-hour mean: arithmetic 24-hour mean; TPM: total particulate matter.

least one of the national standards for criteria pollutants has been exceeded. The other levels, 121-200 and > 200, represent a severe risk to public health. A similar system is currently being used in Rio de Janeiro and other cities in Brazil. ${ }^{13,14}$ For example, in Rio de Janeiro, the Municipal Department of the Environment (SMAC) ${ }^{13}$ and the State Environmental Agency (INEA) ${ }^{14}$ use a five-level scale, ranging from good air quality (0-50) to extremely high pollution (> 300). Between 51 and 100, the air quality is considered "Moderate", from 101 to 200, the air quality is considered "Unhealthy", from 201 to 300 "Very unhealthy" and > 300, "Hazardous". 13,14

\section{Monitoring sites}

In a previous study,$^{10}$ the AQI determined in Rio de Janeiro from July-September 2016 during the Olympic and Paralympic Games, at the monitoring stations operated by SMAC were compiled, and the concentrations of the main criteria pollutants were discussed in terms of the 1990 Brazilian NAQS. The four monitoring stations and the treatment of the monitoring data were fully described in a work published in the Journal of the Brazilian Chemical Society. ${ }^{10}$ In the present study, the same data were analyzed using the new standards. A brief description of the monitoring sites and the data processing is presented here.

During the studied period, SMAC operated eight fixed stations in Copacabana, Tijuca (approximately $2 \mathrm{~km}$ from
Maracanã Stadium), Centro, São Cristóvão, Pedra de Guaratiba, Irajá, Bangu and Campo Grande. ${ }^{10}$ Data were reported to the population as a daily bulletin with the $\mathrm{AQI}$ and the maximum concentration of each determined pollutant. However, during the Olympic and Paralympic Games, only four stations (Tijuca, Irajá, Bangu and Campo Grande) determined all the criteria pollutants. $\mathrm{CO}, \mathrm{SO}_{2}$, $\mathrm{O}_{3}$ and $\mathrm{NO}_{2}$ concentrations were obtained at 10-minute intervals and $\mathrm{PM}_{10}$ in 1-hour intervals. ${ }^{10}$ The main characteristics of each location are presented in Table 4.

\section{Data processing}

Tsuruta et al..$^{10}$ compiled the daily AQI reports as informed by SMAC using the limits shown in Table $5 .^{10,13}$ In this work, AQI were recalculated using the upper limits for good air quality, as shown in Table 5 according to the new resolution (Resolution Number 491, 2018). ${ }^{8}$

The concentrations (1-hour mean) were calculated for the main pollutants $\left(\mathrm{O}_{3}, \mathrm{NO}_{2}\right.$ and $\left.\mathrm{PM}_{10}\right)$. Values for $\mathrm{CO}$ and $\mathrm{SO}_{2}$ were not re-calculated since the previous study showed that these pollutants concentrations remained low during the whole period. ${ }^{10}$ Following the 2018 CONAMA Resolution, ${ }^{8} 8$-hour mean concentrations were also calculated for $\mathrm{O}_{3}$. The maximum daily 8-hour mean concentration was determined by examining 8 -hour running averages, calculated from hourly data and updated each hour. 
Table 4. Description of the studied areas in the city of Rio de Janeiro ${ }^{10}$

\begin{tabular}{|c|c|c|c|}
\hline$\underline{\text { Station }}$ & Coordinates & Population & Characteristics \\
\hline Bangu & $\begin{array}{l}22^{\circ} 53^{\prime} 16.53 ” S \\
43^{\circ} 28^{\prime} 15.91 ” \mathrm{~W}\end{array}$ & 413,000 & $\begin{array}{l}\text { this area is approximately } 20 \mathrm{~km} \text { from the Atlantic coast and is surrounded by the Gericino } \\
\text { (altitude } 970 \mathrm{~m} \text { ) and Pedra Branca (altitude } 1,020 \mathrm{~m} \text { ) mountains, which are natural barriers } \\
\text { for air circulation. Urban area, considered the Rio de Janeiro district with the highes } \\
\text { temperatures and frequent ozone episodes }\end{array}$ \\
\hline Campo Grande & $\begin{array}{l}22^{\circ} 53^{\prime} 10.25 ” \mathrm{~S} \\
43^{\circ} 33^{\prime} 24.12^{\prime \prime} \mathrm{W}\end{array}$ & 358,000 & $\begin{array}{l}\text { urban area in the proximity of the Paciência (altitude } 202 \mathrm{~m} \text { ) and Inhoaíba (altitude } 245 \mathrm{~m} \text { ) } \\
\text { hills. This area has important industrial (plastic, metallurgical, food, pharmaceutical, and } \\
\text { chemical products), commercial and rural activities }\end{array}$ \\
\hline Irajá & $\begin{array}{l}22^{\circ} 49^{\prime} 53.71 ” \mathrm{~S} \\
43^{\circ} 19^{\prime} 36.71 ” \mathrm{~W}\end{array}$ & 461,000 & $\begin{array}{l}\text { this station is located in Nossa Senhora da Apresentação Square, a commercial area near the } \\
\text { Irajá Cemetery. The square contains leisure and open walking areas and hosts cultural events }\end{array}$ \\
\hline Tijuca & $\begin{array}{l}22^{\circ} 55^{\prime} 30.07 ” \mathrm{~S} \\
43^{\circ} 13^{\prime} 57.33^{\prime \prime} \mathrm{W}\end{array}$ & 165,000 & $\begin{array}{l}\text { this station is located at Saens Peña Square. Approximately } 60 \% \text { of its area is urbanized, and } \\
30 \% \text { is covered by Mata Atlantica (tropical rainforest) species. This area is characterized by } \\
\text { commercial activities and a high flux of vehicles and people because of a terminal subway } \\
\text { station, as well as many restaurants, bars and leisure activities. Due to the proximity of the } \\
\text { Tijuca Forest Mountains, maritime breezes do not reach this area }\end{array}$ \\
\hline
\end{tabular}

Table 5. Limits for AQI determined in Resolution Number $491(2018)^{8}$ and values used by SMAC ${ }^{13}$ and CETESB ${ }^{12}$

\begin{tabular}{|c|c|c|c|c|c|c|}
\hline Air quality & $\mathrm{PM}_{10} /\left(\mu \mathrm{g} \mathrm{m}^{-3}\right)$ & $\mathrm{O}_{3} /\left(\mu \mathrm{g} \mathrm{m}^{-3}\right)$ & $\mathrm{CO} / \mathrm{ppm}$ & $\mathrm{NO}_{2} /\left(\mu \mathrm{g} \mathrm{m}^{-3}\right)$ & $\mathrm{SO}_{2} /\left(\mu \mathrm{g} \mathrm{m}^{-3}\right)$ & Reference \\
\hline \multicolumn{7}{|c|}{ AQI limits according the 2018 Brazilian NAQS (Resolution Number 491) } \\
\hline $\begin{array}{l}\text { Good } \\
(0-40)\end{array}$ & $\begin{array}{c}0-50 \\
\text { (24-hour mean) }\end{array}$ & $\begin{array}{c}0-100 \\
\text { (8-hour mean) }\end{array}$ & $\begin{array}{c}0-9 \\
\text { (8-hour mean) }\end{array}$ & $\begin{array}{c}\text { 0-200 } \\
\text { (1-hour mean) }\end{array}$ & $\begin{array}{c}0-20 \\
\text { (24-hour mean) }\end{array}$ & 8 \\
\hline \multicolumn{7}{|c|}{ AQI limits used by SMAC } \\
\hline $\begin{array}{l}\text { Good } \\
(0-50)\end{array}$ & $\begin{array}{c}0-50 \\
\text { (24-hour mean) }\end{array}$ & $\begin{array}{c}0-80 \\
\text { (1-hour mean) }\end{array}$ & $\begin{array}{c}0-4 \\
\text { (8-hour mean) }\end{array}$ & $\begin{array}{c}0-100 \\
\text { (1-hour mean) }\end{array}$ & $\begin{array}{c}0-80 \\
\text { (24-hour mean) }\end{array}$ & \\
\hline $\begin{array}{l}\text { Moderate } \\
(51-100)\end{array}$ & $\begin{array}{c}51-150 \\
\text { (24-hour mean) }\end{array}$ & $\begin{array}{c}81-160 \\
\text { (1-hour mean) }\end{array}$ & $\begin{array}{c}4.1-9 \\
\text { (8-hour mean) }\end{array}$ & $\begin{array}{c}101-320 \\
\text { (1-hour mean) }\end{array}$ & $\begin{array}{c}81-365 \\
\text { (24-hour mean) }\end{array}$ & 13 \\
\hline $\begin{array}{l}\text { Inadequate/unhealthy } \\
(101-199)\end{array}$ & $\begin{array}{c}151-250 \\
\text { (24-hour mean) }\end{array}$ & $\begin{array}{c}161-200 \\
\text { (1-hour mean) }\end{array}$ & $\begin{array}{c}9.1-15 \\
\text { (8-hour mean) }\end{array}$ & $\begin{array}{c}\text { 321-1130 } \\
\text { (1-hour mean) }\end{array}$ & $\begin{array}{c}366-800 \\
\text { (24-hour mean) }\end{array}$ & \\
\hline \multicolumn{7}{|c|}{ AQI limits used by CETESB } \\
\hline $\begin{array}{l}\text { Good } \\
(0-40)\end{array}$ & $\begin{array}{c}0-50 \\
\text { (24-hour mean) }\end{array}$ & $\begin{array}{c}0-100 \\
\text { (8-hour mean) }\end{array}$ & $\begin{array}{c}0-9 \\
\text { (8-hour mean) }\end{array}$ & $\begin{array}{c}0-200 \\
\text { (1-hour mean) }\end{array}$ & $\begin{array}{c}0-20 \\
\text { (24-hour mean) }\end{array}$ & \\
\hline $\begin{array}{l}\text { Moderate } \\
(41-80)\end{array}$ & $\begin{array}{c}>50-100 \\
\text { (24-hour mean) }\end{array}$ & $\begin{array}{c}>100-130 \\
(8 \text {-hour mean })\end{array}$ & $\begin{array}{c}>9-11 \\
\text { (8-hour mean) }\end{array}$ & $\begin{array}{c}>200-240 \\
(1-\text { hour mean })\end{array}$ & $\begin{array}{c}>20-40 \\
(24-\text { hour mean })\end{array}$ & 12 \\
\hline $\begin{array}{l}\text { Unhealthy } \\
(81-120)\end{array}$ & $\begin{array}{c}>100-150 \\
(24-\text { hour mean })\end{array}$ & $\begin{array}{c}>130-160 \\
(8 \text {-hour mean })\end{array}$ & $\begin{array}{c}>11-13 \\
\text { (8-hour mean) }\end{array}$ & $\begin{array}{c}>240-320 \\
(1 \text {-hour mean })\end{array}$ & $\begin{array}{c}>40-365 \\
(24 \text {-hour mean })\end{array}$ & \\
\hline
\end{tabular}

$\mathrm{PM}_{10}$ : particles that have aerodynamic diameters less than or equal to $10 \mu \mathrm{m}$; AQI: air quality index; NAQS: National Air Quality Standards; SMAC: Municipal Department of the Environment; CETESB: São Paulo State Environmental Agency.

\section{Results and Discussion}

The AQI informed by SMAC were calculated using the 5-level classification: "Good" (<50), "Moderate" (51-100), "Inadequate/unhealthy" (101-200), "Very unhealthy" (201-300) and "Hazardous" (> 300), as shown in Table 5.13 The AQI calculation is detailed by SMAC and is also presented as Supplementary Information (SI, equation S1). ${ }^{13}$

Values were recalculated for this work and are shown in Figure 1, in good agreement with the SMAC daily report. For consistency with SMAC AQI, values were calculated using the data for the period between 3:00 p.m. on the previous day and 2:59 p.m. on that day. As discussed by Tsuruta et al., ${ }^{10}$ the worst air quality conditions were observed at Bangu and Irajá stations.

In Irajá, the ozone concentration value of $201 \mu \mathrm{g} \mathrm{m}^{-3}$ was exceeded on two days (August 16 and September 18), leading to an AQI > 200 ("Very unhealthy" air quality), considering the SMAC reports. ${ }^{13}$ In Bangu, the 1990 ozone air quality standard (1-hour mean, $160 \mathrm{\mu g} \mathrm{m}^{-3}$ ) was exceeded on 4, 2 and 3 days in July, August and September, respectively, leading to an AQI $>100$. In Irajá, the AQI was $>100$, due to ozone concentrations, on 3 and 4 days in July and August, respectively. ${ }^{10}$

Figure 1 also shows the recalculated AQI using the limits proposed by CETESB ${ }^{12}$ and the 2018 CONAMA 

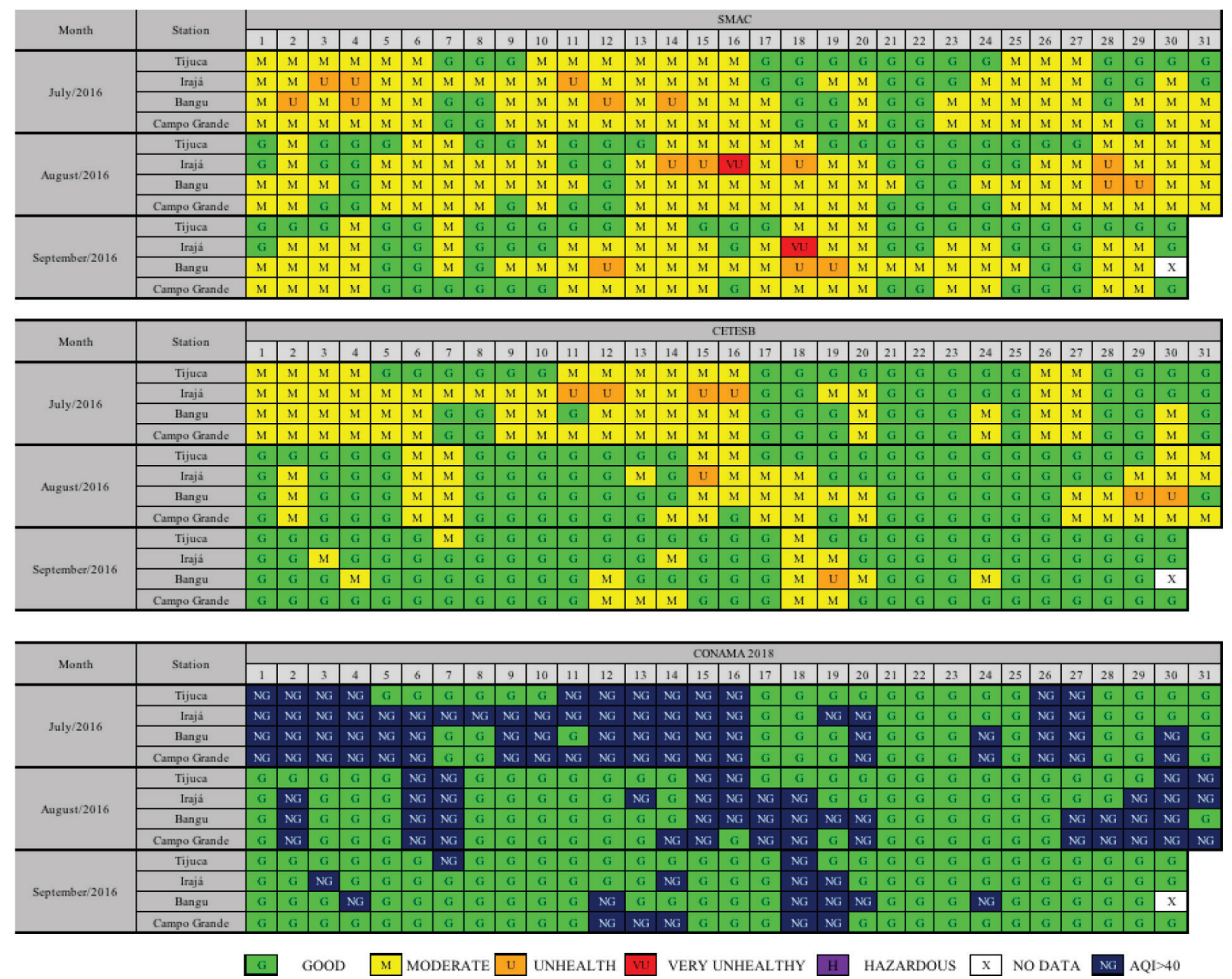

Figure 1. AQI from July-September 2016 determined using the data collected by the automatic monitoring stations: Tijuca, Irajá, Bangu and Campo Grande as calculated by SMAC ${ }^{13}$ and as calculated in this study using the limits determined by Resolution Number $491^{8}$ (for the "Good" condition) and the limits determined by CETESB ${ }^{12}$ for the other conditions.

Resolution $^{8}$ (Table 5). The equation used to compute the AQI is the same (equation $\mathrm{S} 1$, SI section), but the final values are different because the limits are not the same. The maximum daily 8 -hour mean ozone concentrations were selected by examining 8-hour running averages, calculated from hourly data and updated each hour. The first calculation period for any one day was the period between 7:00 a.m. and 2:59 p.m. on the previous day, and the last calculation period for any one day was the period from 7:00 a.m. to 2:59 p.m. on that day. As shown in Table 5, the first intervals ("Good") used by CETESB ${ }^{12}$ and indicated by Resolution Number $491^{8}$ are equal. Since the CONAMA 2018 Resolution $^{8}$ does not indicate limiting values for $\mathrm{AQI}>40$, the values were indicated in Figure 1 as NG (AQI > 40).

In Figure 2, the percentage of days with air quality levels of "Good", "Moderate", "Unhealthy" and "Very unhealthy" are presented, for each studied location, considering the limits for the AQI used by SMAC,,$^{13}$ CETESB $^{12}$ and proposed by the CONAMA 2018 Resolution. ${ }^{8}$
As reported by $\mathrm{SMAC}^{13}$ in Tijuca, Irajá, Bangu and Campo Grande, respectively, 60.9, 33.7, 17.6 and $31.5 \%$ of the days presented a "Good" AQI. Using the limits proposed by CETESB ${ }^{12}$ and the new resolution, ${ }^{8}$ the percentages are $78.3,62.0,59.3$ and $59.8 \%$, respectively. To understand these differences, a detailed analysis of each pollutant is necessary.

An important contribution of Resolution Number $491^{8}$ is the inclusion of $\mathrm{PM}_{2.5}$ as a criteria pollutant. WHO documents clearly show the effects of short- and long-term exposure, including mortality, cardiovascular disease morbidity and cancer risk. ${ }^{9,11}$ Since these data were not obtained by the four studied monitoring stations, they cannot be included in AQI calculations. Using the available data and SMAC AQI,${ }^{10}$ in Tijuca, the main pollutant (which led to a higher $\mathrm{AQI}$ ) was $\mathrm{NO}_{2}$ on $58.7 \%$ of the studied days, while in Irajá, Bangu and Campo Grande the main pollutant was $\mathrm{O}_{3}$ on $76.1,90.1$ and $62.2 \%$ of the days, respectively.

Maximum ozone concentrations (1-hour mean) remained high, as shown in Figure 3, and led to "Moderate" 


\begin{tabular}{|c|c|cc|c|c|}
\hline \multicolumn{7}{|c|}{ Tijuca } \\
\hline AQI & G & M & U & VU & NG \\
\hline SMAC & 60.9 & 39.1 & 0.0 & 0.0 & - \\
\hline CETESB & 78.3 & 21.7 & 0.0 & 0.0 & - \\
\hline CONAMA 2018 & 78.3 & - & - & - & 21.7 \\
\hline
\end{tabular}

\begin{tabular}{|c|c|cc|c|c|}
\hline \multicolumn{7}{|c|}{ Irajá } \\
\hline AQI & G & M & U & VU & NG \\
\hline SMAC & 33.7 & 56.5 & 7.6 & 2.2 & - \\
CETESB & 62.0 & 32.6 & 5.4 & 0.0 & - \\
CONAMA 2018 & 62.0 & - & - & - & 38.0 \\
\hline
\end{tabular}

\begin{tabular}{|c|c|cc|c|c|}
\hline \multicolumn{7}{|c|}{ Bangu } \\
\hline AQI & G & M & U & vU & NG \\
\hline SMAC & 17.6 & 72.5 & 9.9 & 0.0 & - \\
CETESB & 59.3 & 37.4 & 3.3 & 0.0 & - \\
CONAMA 2018 & 59.3 & - & - & - & 40.7 \\
\hline
\end{tabular}

\begin{tabular}{|c|c|cc|c|c|}
\hline \multicolumn{7}{|c|}{ Campo Grande } \\
\hline AQI & $\mathrm{G}$ & $\mathrm{M}$ & $\mathrm{U}$ & $\mathrm{vU}$ & $\mathrm{NG}$ \\
\hline SMAC & 31.5 & 68.5 & 0.0 & 0.0 & - \\
CETESB & 59.8 & 40.2 & 0.0 & 0.0 & - \\
\hline CONAMA 2018 & 59.8 & - & - & - & 40.2 \\
\hline
\end{tabular}

Figure 2. Percentage of days with air quality indexes of "Good" $(\mathrm{G})$, "Moderate" (M), "Unhealthy" (U) and "Very unhealthy" (VU), during July-September 2016, determined using the data collected by the automatic monitoring stations of Tijuca, Irajá, Bangu and Campo Grande as calculated by $\mathrm{SMAC}^{13}$ and as calculated in this study using the limits determined by CETESB ${ }^{12}$ and the limits determined by Resolution $491^{8}$ (for the "Good" condition). Using CONAMA 2018 Resolution, ${ }^{8}$ values for $\mathrm{AQI}>40$ were indicated as NG.

(a) Tijuca

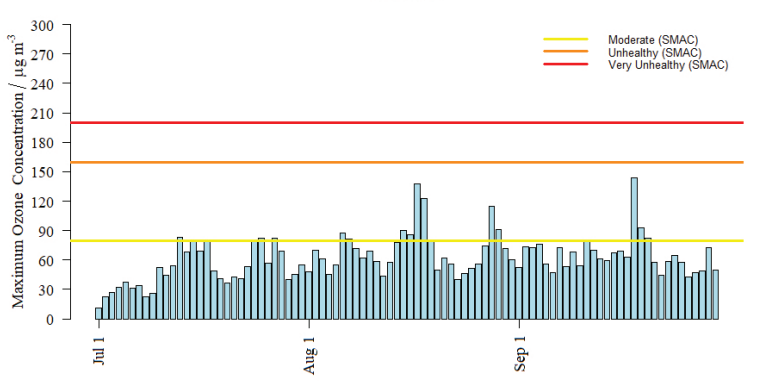

(c) Bangu

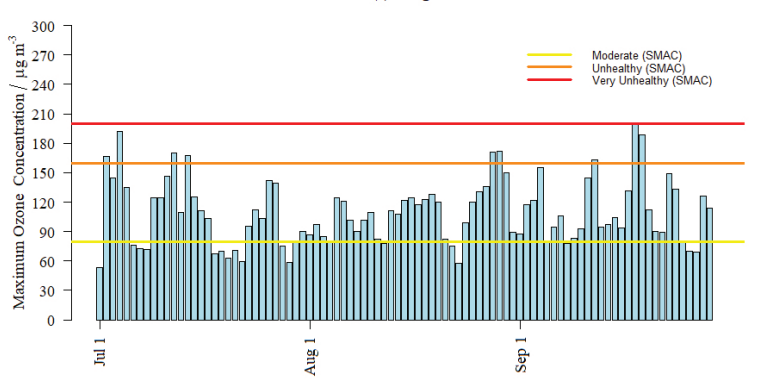

and "Unhealthy" AQI at the four monitoring stations. These maximum values were calculated for the period between 3:00 p.m. on the previous day and 2:59 p.m. on that day, for consistency with the AQI calculations. The same procedure was followed in Figures 4-6. Data were processed using an $\mathrm{R}$ code. ${ }^{15}$

In Figure 4, the maximum 8-hour mean is shown together with the 2018 CONAMA Resolution limits. ${ }^{8}$ When considering these limits, the number of days with a "Good" $\mathrm{AQI}$ increases for Irajá, Bangu and Campo Grande. $\mathrm{O}_{3}$ was the pollutant that led to higher AQI on 28.3, 62.2 and $23.9 \%$ of days, respectively. The increase of the averaging period from 1 to $8 \mathrm{~h}$ favors the calculation of lower indexes. Notably, the line at $100 \mu \mathrm{g} \mathrm{m}^{-3}$ indicates the "Moderate" $\mathrm{AQI}$, as determined by CETESB, ${ }^{12}$ and the $\mathrm{AQI}>40$ follows the 2018 CONAMA Resolution. ${ }^{8}$

Brazilian air quality standards for ozone can also be compared with national standards for other countries: US National Ambient Air Standards (US EPA NAAQS) ${ }^{16}$ and California Air Resources Board Ambient Air Quality Standards (CARB AQS), ${ }^{1718}$ European Union Directive 2008/50/EC, ${ }^{19}$ and environmental air quality standards in Japan ${ }^{20}$ and Australia. ${ }^{21}$ Values are shown in Table 6.

In 2005, after an extensive review of the scientific literature, CARB approved an 8-hour standard for ozone of $0.070 \mathrm{ppm}$ (approximately $140 \mu \mathrm{g} \mathrm{m}^{-3}$ ) and retained the 1-hour $0.09 \mathrm{ppm}$ (approximately $180 \mathrm{\mu g} \mathrm{m}^{-3}$ ) standard previously established in $1987 .{ }^{18}$ In 2015 , the US EPA lowered the national 8-hour standard from $0.075 \mathrm{ppm}$
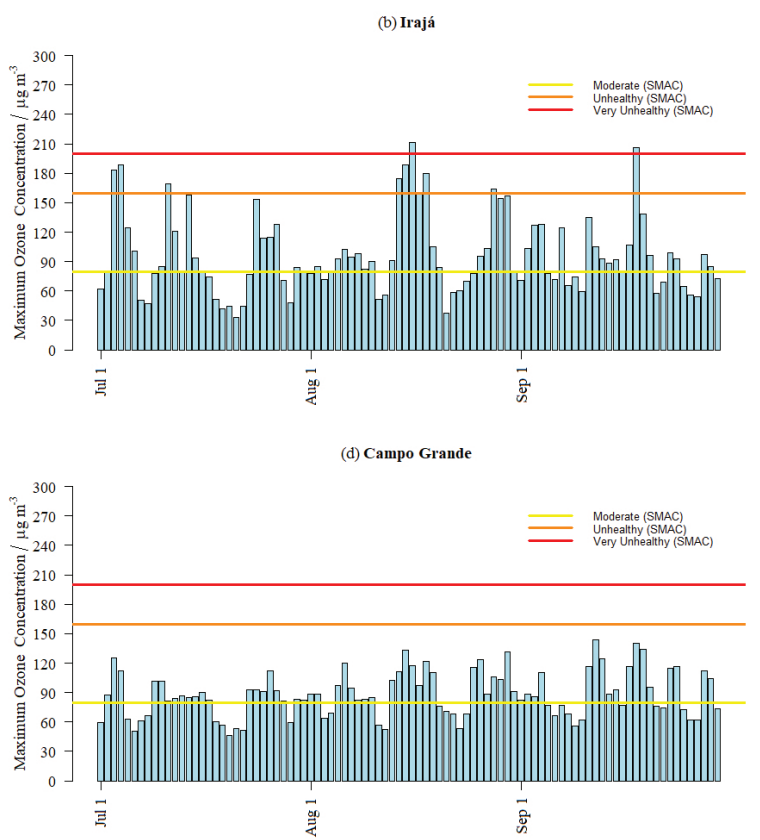

Figure 3. Maximum ozone concentrations (1-hour mean) in the period from July 1, 2016 to September 30, 2016 for: (a) Tijuca; (b) Irajá; (c) Bangu; (d) Campo Grande. The limits of 80, 160 and $200 \mu \mathrm{g} \mathrm{m}^{-3}$ are also indicated, which indicate the AQI levels of "Good" $\left(0-80 \mu \mathrm{g} \mathrm{m} \mathrm{m}^{-3}\right)$, "Moderate" $\left(81-160 \mu \mathrm{g} \mathrm{m} \mathrm{m}^{-3}\right)$ and "Inadequate/Unhealthy" (161-200 $\left.\mu \mathrm{g} \mathrm{m}^{-3}\right)$. See Table 5 for more details. 

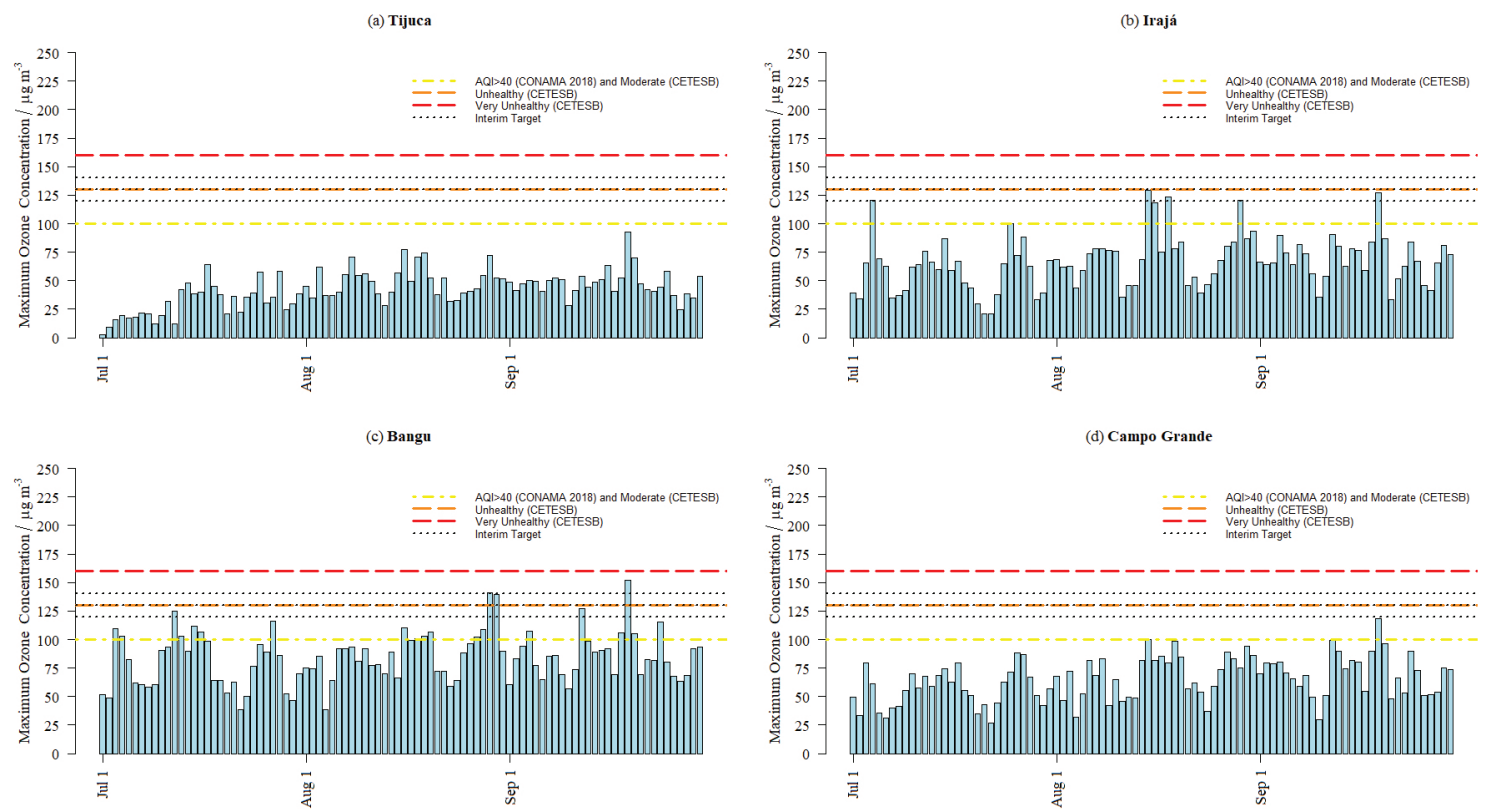

Figure 4. Maximum ozone concentrations (8-hour mean) from the period July 1, 2016 to September 30, 2016 for: (a) Tijuca; (b) Irajá; (c) Bangu; (d) Campo Grande. The limits are 140 (IT-1), 130 (IT-2), 120 (IT-3) and 100 (NAQS) $\mu \mathrm{g} \mathrm{m}^{-3}$. The value of $100 \mu \mathrm{g} \mathrm{m} \mathrm{m}^{-3}$ is the limit for "Good" AQI both for CETESB ${ }^{12}$ and the 2018 Resolution. ${ }^{8}$ The values of 130 and $160 \mu \mathrm{g} \mathrm{m}^{-3}$ are the lower limits for the "Moderate" and "Unhealthy" AQI, respectively, following CETESB. ${ }^{12}$ See Table 5 for more details.
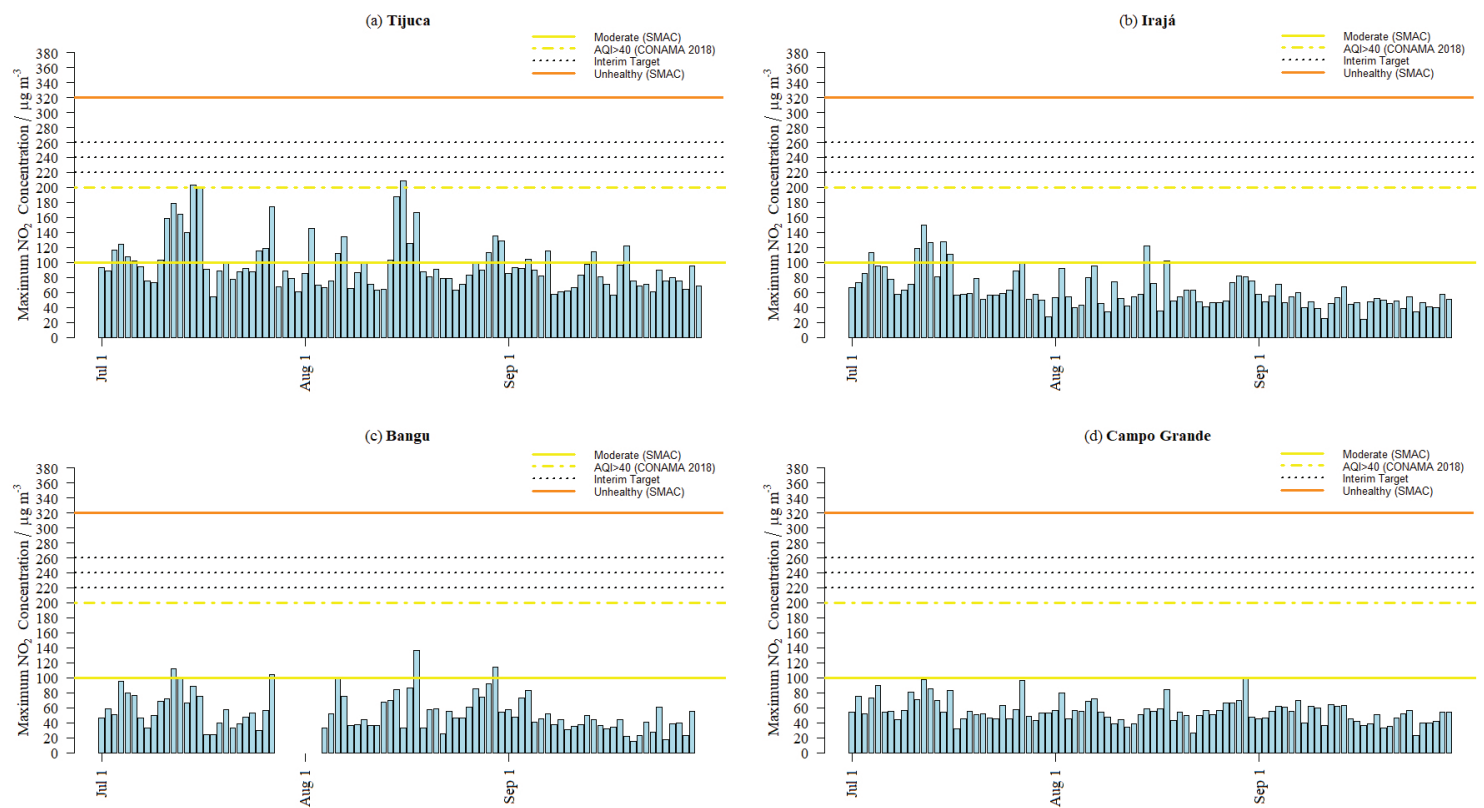

Figure 5. Maximum $\mathrm{NO}_{2}$ concentrations (1-hour mean) from the period July 1, 2016 to September 30, 2016 for: (a) Tijuca; (b) Irajá; (c) Bangu; (d) Campo Grande. The limits of 100 and $320 \mu \mathrm{g} \mathrm{m}^{-3}$ are also shown, which indicate the "Good" (0-100 $\left.\mu \mathrm{g} \mathrm{m}^{-3}\right)$ and "Moderate" (101-320 $\left.\mu \mathrm{g} \mathrm{m} \mathrm{m}^{-3}\right) \mathrm{AQI}$ according to the SMAC report. ${ }^{13}$ The value $200 \mathrm{\mu g} \mathrm{m}^{-3}$ indicates the "Good" $\left(0-200 \mu \mathrm{g} \mathrm{m}^{-3}\right)$ AQI according to the $2018 \mathrm{CONAMA} \mathrm{Resolution}^{8}$ and CETESB ${ }^{12}$ and the values 240 and $320 \mu \mathrm{g} \mathrm{m}^{-3}$ indicate the "Moderate" (> 200-240 $\mu \mathrm{g} \mathrm{m}^{-3}$ ) and "Unhealthy" (> 240-320 $\left.\mu \mathrm{g} \mathrm{m}^{-3}\right)$ AQI according CETESB. ${ }^{12}$ See Table 5 for more details. Missing data in Figure $5 \mathrm{c}$ were not reported by the monitoring station.

(approximately $150 \mu \mathrm{g} \mathrm{m}^{-3}$ ) to $0.070 \mathrm{ppm}$ (approximately $140 \mathrm{\mu g} \mathrm{m}^{-3}$ ), both for primary and secondary standards. The 8-hour standard is higher than the values established by the new CONAMA resolution $\left(140,130,120\right.$ and $100 \mu^{-3} \mathrm{~m}^{-3}$ for the IT-1, IT-2, IT-3 and final standard, respectively). According to $\mathrm{CARB},{ }^{17,18}$ 1-hour ozone concentrations do not define lower AQI values (i.e., "Good" (0-50) and "Moderate" (51-100)). Thus, AQI values of 100 or less are calculated with the 8-hour means. The limits of 50 and 100 for the AQIs correspond to ozone concentrations of 106 and $137 \mu \mathrm{g} \mathrm{m}^{-3}$, respectively. These values are similar to those adopted by CETESB. ${ }^{12}$ 

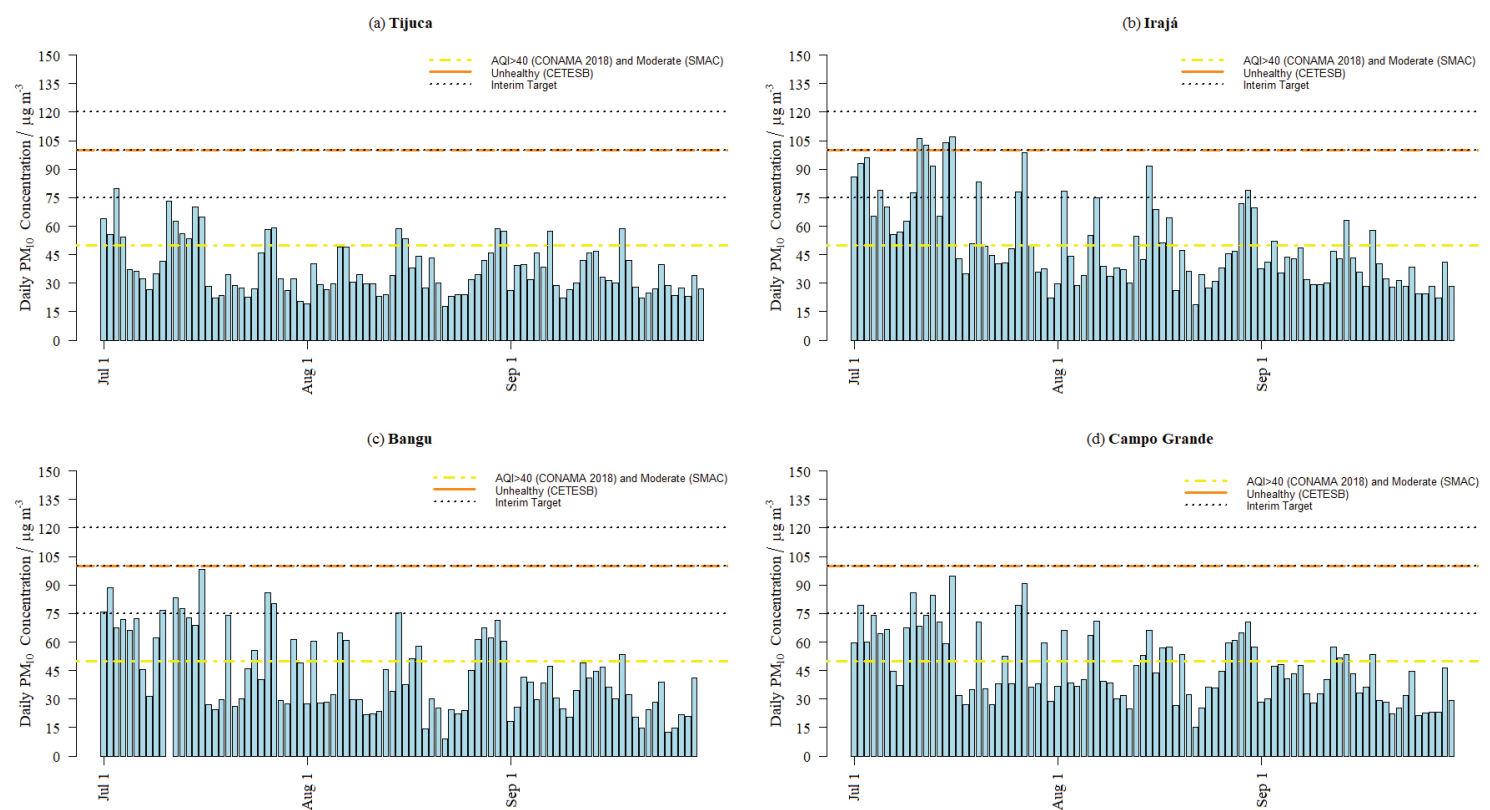

Figure 6. Daily $\mathrm{PM}_{10}$ concentrations (24-hour mean) in the period from July 1, 2016 to September 30, 2016 for: (a) Tijuca; (b) Irajá; (c) Bangu; (d) Campo Grande. The limits of $150 \mu \mathrm{g} \mathrm{m}^{-3}$ (1990 CONAMA Resolution), ${ }^{4} 120,100,75$ and $50 \mu \mathrm{g} \mathrm{m}^{-3}$ for the IT-1, IT-2, IT-3 and final standard, respectively, according to the 2018 CONAMA Resolution, ${ }^{8}$ are also shown for reference. The limits of 50 and $150 \mathrm{\mu g} \mathrm{m}^{-3}$ indicate the "Good" $\left(0-50 \mu \mathrm{g} \mathrm{m}{ }^{-3}\right)$ and "Moderate" (51-150 $\mu \mathrm{g} \mathrm{m} \mathrm{m}^{-3}$ ) AQI according to the SMAC report, ${ }^{13} 2018$ CONAMA Resolution ${ }^{8}$ and CETESB..$^{12}$ The values 100 and $150 \mu \mathrm{g} \mathrm{m}{ }^{-3}$ indicate the "Moderate" AQI according CETESB ${ }^{12}\left(>50-100 \mu \mathrm{g} \mathrm{m}^{-3}\right)$ and $\operatorname{SMAC}^{13}\left(51-150 \mu \mathrm{g} \mathrm{m}^{-3}\right)$.

Table 6. Ozone AQSs and interim targets (IT) determined in Brazil, in 2018, and values established in other countries

\begin{tabular}{|c|c|c|c|}
\hline Country/legislation & $\begin{array}{l}\text { 8-hour mean / } \\
\qquad\left(\mu \mathrm{g} \mathrm{m}^{-3}\right)\end{array}$ & $\begin{array}{l}\text { 1-hour mean / } \\
\left(\mu \mathrm{g} \mathrm{m}^{-3}\right)\end{array}$ & Note \\
\hline $\begin{array}{l}\text { Brazil } \\
\text { (CONAMA 1990) }\end{array}$ & - & 160 & $\begin{array}{l}\text { should not be exceeded more than once per year } \\
\text { reference } 4\end{array}$ \\
\hline $\begin{array}{l}\text { Brazil } \\
\text { (IT-1, CONAMA, 2018) }\end{array}$ & 140 & - & reference 8 \\
\hline $\begin{array}{l}\text { Brazil } \\
\text { (IT-2, CONAMA, 2018) }\end{array}$ & 130 & & reference 8 \\
\hline $\begin{array}{l}\text { Brazil } \\
\text { (IT-3, CONAMA, 2018) }\end{array}$ & 120 & & reference 8 \\
\hline $\begin{array}{l}\text { Brazil } \\
\text { (Final value, CONAMA, 2018) }\end{array}$ & 100 & & reference 8 \\
\hline US EPA NAAQS & $140^{\mathrm{a}}$ & - & $\begin{array}{l}\text { annual fourth-highest daily maximum } 8 \text {-hour concentration, } \\
\text { averaged over } 3 \text { years } \\
\text { reference } 16\end{array}$ \\
\hline CARB AQS & $140^{\mathrm{a}}$ & $180^{\mathrm{a}}$ & reference 18 \\
\hline EU Directive 2008/50/EC & 120 & - & $\begin{array}{c}\text { should not be exceeded more than } 25 \text { days per calendar year } \\
\text { averaged over three years } \\
\text { reference } 19\end{array}$ \\
\hline AQS Japan & - & $120^{\mathrm{a}}$ & reference 20 \\
\hline AQS Australia & & $200^{\mathrm{a}}$ & $\begin{array}{c}\text { the value of } 160 \mu \mathrm{g} \mathrm{m}^{-3} \text { is applied over a 4-h period } \\
\text { reference } 21\end{array}$ \\
\hline
\end{tabular}

an the original documentation, values are reported in units of $\mathrm{ppm}$. In this table, they were transformed to units of $\mu \mathrm{g} \mathrm{m}^{-3}$ for a better comparison. The conversion factor $1 \mathrm{ppm}=40.9 \times(\mathrm{MW}) \mu \mathrm{g} \mathrm{\textrm {m } ^ { - 3 }}$ was used. Considering $\mathrm{MW}=48$, this factor is approximately 2000 .

The target value established by the European Union (EU) in 2008 (to be met by 2010), through Directive 2008/50/EC, ${ }^{19}$ was $120 \mu \mathrm{g} \mathrm{m}^{-3}$ for the 8-hour mean, which should not be exceeded more than 25 days per calendar year averaged over three years. This EU Directive also established how the calculation should be performed: 
the maximum daily 8 -hour mean concentration should be selected by examining 8-hour running averages, calculated from hourly data and updated each hour. The first calculation period for any one day should be the period between 5:00 p.m. on the previous day and 1:00 a.m. on that day, and the last calculation period for any one day should be the period from 4:00 p.m. to 0:00 a.m. on that day. ${ }^{19}$

Japan adopted a 1-hour mean of $0.06 \mathrm{ppm}$ (approximately $120 \mu \mathrm{g} \mathrm{m}^{-3}$ ). This limit applies to all photochemical oxidants (including ozone and peroxyacetyl nitrate produced by photochemical reactions excluding $\mathrm{NO}_{2}$ ). This limit is difficult to achieve in Japanese urban areas, leading to a large number of days when alerts and warnings are issued. ${ }^{22}$

The Japanese value, ${ }^{20}$ for a 1 -hour mean, is lower than the $\mathrm{CARB}^{17,18}(0.09 \mathrm{ppm})$ and Australian ${ }^{21}(0.100 \mathrm{ppm}$, approximately $200 \mathrm{\mu g} \mathrm{m}^{-3}$ ) standards. For the 8-hour mean, the US EPA and CARB have established values higher than the WHO recommendation $\left(100 \mu \mathrm{g} \mathrm{m}^{-3}\right)$. Considering the WHO recommendation of revising the limit proposed in $2005,{ }^{11}$ as well as the results presented in Figures 2-5, it seems clear that values established by CONAMA in $2018^{8}$ are too high, mainly considering that there has not been determined data for adopting the final target value of $100 \mu \mathrm{g} \mathrm{m}^{-3}$ (8-hour mean).

The daily maximum $\mathrm{NO}_{2}$ concentrations (1-hour mean) are shown in Figure 5, as well as the limits of 100 and $200 \mathrm{~g} \mathrm{~m} \mathrm{~m}^{-3}$. As detailed in Table 5, in 2016, $\mathrm{SMAC}^{13}$ used the values of 100 and $320 \mathrm{\mu g} \mathrm{m}^{-3}$ as the limits for the "Good" and "Moderate" AQI, respectively. According to the 2018 CONAMA Resolution, ${ }^{8}$ the limit for a "Good" AQI is $200 \mathrm{~g} \mathrm{~m} \mathrm{~m}^{-3}$. The line at $200 \mathrm{\mu g} \mathrm{m}^{-3}$ indicates the "Moderate" $\mathrm{AQI}$ as determined by CETESB, and the AQI $>40$ follows the 2018 CONAMA Resolution. ${ }^{8}$

As previously mentioned, in Tijuca, $\mathrm{NO}_{2}$ concentrations were higher than $100 \mathrm{\mu g} \mathrm{m}^{-3}$ on $58.7 \%$ of days. When considering the new limit $\left(200 \mu \mathrm{g} \mathrm{m}^{-3}\right)$, the value was higher only on $1.1 \%$ of days in Tijuca, and the standard was adhered to over the entire time period in the other three locations.

Daily $\mathrm{PM}_{10}$ concentrations (24-hour mean) are shown in Figure 6, as well as the limits of $150 \mu \mathrm{g} \mathrm{m}^{-3}$ (1990 CONAMA Resolution), ${ }^{4} 120,100,75$ and $50 \mu \mathrm{g} \mathrm{m}^{-3}$ for the IT-1, IT-2, IT-3 and final standard, respectively, according to the 2018 CONAMA Resolution. ${ }^{8}$ The AQI "Good" limit is $50 \mu \mathrm{g} \mathrm{m}^{-3}$ (24-hour mean) for the $\mathrm{SMAC}^{13}$ and CETESB ${ }^{12} \mathrm{AQI}$ and also for the new resolution. ${ }^{8}$ As previously stated, the new resolution does not indicate the limit for a "Moderate" AQI, and values $>50 \mu \mathrm{g} \mathrm{m}^{-3}$ are considered an AQI $>40$ (i.e., a value higher than the "Good" limit). Since the AQIs calculated for $\mathrm{O}_{3}$ and $\mathrm{NO}_{2}$ are lower considering the 2018 CONAMA limits, the importance of $\mathrm{PM}_{10}$ increased and the percentage of days on which the higher AQI was due to this pollutant became more important on $89.1,71.7,37.4$ and $76.1 \%$ of the days for Tijuca, Irajá, Bangu and Campo Grande, respectively.

When comparing the two CONAMA resolutions, ${ }^{4,8}$ the new legislation is clearly more restrictive regarding particulate matter, in good agreement with the new evidence about $\mathrm{PM}_{10}$ and $\mathrm{PM}_{2.5}$ toxicity and the increased cancer risk, also at levels below the current WHO guideline. ${ }^{11}$ The inclusion of $\mathrm{PM}_{2.5}$ is an important improvement. In spite of this advancement, the IT- 1 values are too high: for $\mathrm{PM}_{10}, 40$ (annual mean) and $120 \mu \mathrm{g} \mathrm{m}^{-3}$ (24-hour mean) in comparison to the values recommended by WHO (20 and $50 \mu \mathrm{g} \mathrm{m}^{-3}$, respectively). ${ }^{9}$ For $\mathrm{PM}_{2.5}$, the IT- 1 values are 20 (annual mean) and $60 \mathrm{\mu g} \mathrm{m}^{-3}$ (24-hour mean) in comparison to the values recommended by WHO (10 and $25 \mu \mathrm{g} \mathrm{m}^{-3}$, respectively). ${ }^{9}$ The new CONAMA resolution ${ }^{8}$ established that the IT-2, IT-3 and final NAQS should be adopted considering the reports and planning by environmental agencies (states and the Federal District). The IT-1 values do not meet the conditions to protect the health and welfare of the population. ${ }^{9}, 11$ Since the legislation has not established a data limit to meet the standards, the values are, in fact, permissive and ineffective at protecting public health. ${ }^{23}$ As highlighted in the 2005 WHO recommendations, ${ }^{9}$ researchers have not identified thresholds below which adverse effects do not occur; thus, the guideline values cannot fully protect human health. Certainly, the IT-1 values, which are higher than WHO guidelines, are also ineffective at this task, which is a fundamental human right.

The NAQS for $\mathrm{NO}_{2}$ (1-hour mean) has been reduced from 320 to $260,240,220$ and $200 \mu \mathrm{g} \mathrm{m}^{-3}$ for the IT-1, IT-2, IT-3 and final value, respectively. However, the IT-1 value for ozone $\left(140 \mu \mathrm{g} \mathrm{m}^{-3}\right)$ is too high in comparison to the final value $\left(100 \mu \mathrm{g} \mathrm{m}^{-3}\right)$. Moreover, it seems clear that limits for $\mathrm{O}_{3}$ are probably very permissible considering the revision recommendations. ${ }^{11}$ Several studies on the health effects of ozone have been published since 2005, showing evidence of effects at levels below $100 \mu \mathrm{g} \mathrm{m}^{-3}$ for an average 8-hour mean exposure. ${ }^{24,25} \mathrm{WHO}$ also recommended considering short-term averaging times. ${ }^{11}$ Considering the geographic and climatic conditions of Brazil, with high temperatures and solar radiation, which favors ozone formation, a lower value for the target limit (100 $\mu \mathrm{g} \mathrm{m}^{-3}$ for an 8-hour average) may be necessary to protect public health. As discussed in the 2016 CETESB Air Quality Report (for São Paulo State), ${ }^{26}$ the pollutants of major concern are particulate matter, mainly in the dry period (May to August), and ozone, mainly in the transition between the dry and rainy period (September and October), when the solar insolation is high and the cloud cover is low. Data for Rio de Janeiro, 
as discussed in this study, also show that ozone episodes are the main cause of inadequate air quality.

In contrast, data for AQIs calculated for megacities around the world, using the CARB standards, show that in Europe and Asia, particulate matter, and mainly $\mathrm{PM}_{2.5}$, is the main pollutant. ${ }^{27}$ In São Paulo (Brazil), according to data provided by CETESB,${ }^{28} 59$ and $18 \%$ of monitoring stations determine $\mathrm{PM}_{2.5}$ in the capital and the metropolitan region, respectively. For these stations, $\mathrm{PM}_{2.5}$ frequently appears as the main pollutant as well as in other major cities in South America (Lima, Buenos Aires, Santiago de Chile, Medellin, and Quito) included in the Real Time Air Quality Index Visual Map. ${ }^{27}$ The lack of $\mathrm{PM}_{2.5}$ data for Brazilian cities results in the calculation of lower AQI, leading to an ostensibly good air quality as shown in Figure 1. In particular, in Rio de Janeiro, $\mathrm{PM}_{2.5}$ levels are either not determined or not reported to the population, and they are not used in the AQI calculation. The IT-1 limits for the annual and 24-hour mean are 20 and $60 \mu \mathrm{g} \mathrm{m}{ }^{-3}$, respectively. ${ }^{8}$ Although these limits should have been applied since November 2018, the resolution established that regulatory agencies should elaborate a regulatory program for controlling atmospheric emissions within three years to meet these standards. Air quality is monitored in São Paulo, ${ }^{29}$ Rio de Janeiro, ${ }^{30,31}$ Bahia and Rio Grande do Sul ${ }^{32,33}$ and for a limited number of pollutants in a very limited number of stations in Minas Gerais, ${ }^{34}$ Goiás, Espírito Santo, ${ }^{35}$ Sergipe, Paraná and the Federal District. ${ }^{7,36-38}$ Considering that the cost of a complete monitoring station has been estimated at between US\$ 350,000 and 500,000 and that a station also requires highly qualified technical staff and high maintenance costs, the real application of the 2018 CONAMA Resolution NAQS seems a difficult task.

Additionally, the high $\mathrm{NO}_{2}$ and $\mathrm{O}_{3}$ values determined in Rio de Janeiro and other Brazilian cities indicate that these pollutants should not be dismissed considering the use of ethanol-blended gasoline and compressed natural gas and the climatic conditions (high insolation and temperatures), which may lead to a different composition of vehicular emissions (compared to Europe) and to the formation of other secondary photochemical pollutants. Furthermore, other pollutants in group 2 (Table 2) should be monitored considering the evidence regarding adverse health effects.

\section{Future perspectives}

Resolution Number $491^{8}$ was published in November 19, 2018, after several years of discussions, in spite of the unfavorable opinion of experts in environmental and health sciences and the scientific evidence of the air pollution impact on public health. ${ }^{1,9,11,38}$ In May 2019, the office of the Prosecutor General (Procuradoria Geral da Republica) filed a Direct Action of Unconstitutionality ${ }^{39}$ based on the evidence that the 2018 CONAMA Resolution does not meet the main goal of protecting public health.

Results presented in this study clearly support the requirement of improvement of the new resolution. Furthemore, in a recent study Lelieveld et al. ${ }^{40}$ reported new data, based on novel hazard ratio functions, suggesting that the health impacts attributable to ambient air pollution in Europe are substantially higher than previously assumed, though subject to considerable uncertainty. The authors estimated that the attributable excess mortality rate is about 8.79 million per year with and overall uncertainty of $\pm 50 \%$, a number considerable higher than the value reported by $\mathrm{WHO}^{1}$

Considering these evidences and the fact that the IT-1 values are too high in comparison to recommended values, ${ }^{9}$ the legislation should establish a limit data to meet interim values and the final standards. Also, it should establish clear procedures in order to ensure that the information collected on air pollution is sufficiently representative and comparable across the states and that standardized measurement techniques and common criteria for the number and location of measuring stations are used for the assessment of ambient air quality. The resolution should also establish the limit values to calculate the AQI ("Moderate", "Unhealthy", "Very unhealthy" and "Hazardous") and clear procedures to inform the population about the risks related to the exceedance of these limits.

It should be also appropriate to provide for the possibility of adapting the final standards and techniques used for the assessment of the ambient air quality to scientific and technical progress and establish a data for revision of legislation.

Other compounds included in group 2 may be considered. In particular, results obtained in Rio de Janeiro showed that benzene concentrations frequently exceeded the value of $5 \mu \mathrm{g} \mathrm{m}^{-3}$, established by the European Union (EU) Directive 2000/69/EC, as the permissible limit for the annual average concentration in ambient air. ${ }^{41-44}$ Considering that the WHO have reported that there are no safe exposure limits for benzene, ${ }^{9,11}$ fixed measurements by the monitoring stations should be established for densely populated urban areas.

\section{Conclusions}

In 1990, the first NAQS were established and represented an important contribution to air quality protection and management. After 30 years, considering 
the accumulated scientific evidence regarding the health effects of air pollution, these limits were clearly too high. The new NAQS were approved in 2018, after more than six years of discussions, and followed the WHO 2005 recommendations. Interim targets (IT-1, IT-2 and IT-3) were proposed for each pollutant as incremental steps in a progressive reduction of air pollution down to the final value. Since a deadline to meet these limit values has not been established, and the IT-1 values for the main pollutants $\left(\mathrm{PM}_{10}, \mathrm{PM}_{2.5}\right.$ and $\left.\mathrm{O}_{3}\right)$ are very permissive in comparison to the final values and the limits proposed by WHO, the 2018 CONAMA Resolution does not meet the main goal of protecting public health. Experimental data presented in this study confirm that AQIs calculated using the new values would suggest a "false good" for air quality, mainly when calculated without considering $\mathrm{PM}_{25}$ levels.

\section{Supplementary Information}

Details about the calculation of AQI are available free of charge at http://jbcs.sbq.org.br as PDF file.

\section{Acknowledgments}

The authors acknowledge data provided by the Municipal Department of the Environment (SMAC) and financial support from the Coordenação de Aperfeiçoamento de Pessoal de Nível Superior (CAPES) and the National Counsel of Technological and Scientific Development (CNPq).

\section{References}

1. https://www.who.int/airpollution/ambient/en/, accessed in August 2019.

2. https://www.who.int/en/news-room/detail/27-09-2016-whoreleases-country-estimates-on-air-pollution-exposure-andhealth-impact, accessed in August 2019.

3. https://www.who.int/phe/health_topics/outdoorair/databases/ cities/en/, accessed in August 2019.

4. http://www2.mma.gov.br/port/conama/legiabre. cfm?codlegi=100, accessed in August 2019.

5. http://apps.who.int/iris/bitstream/handle/10665/107335/ E71922.pdf? sequence $=1 \&$ isAllowed $=y$, accessed in August 2019.

6. https://www2.camara.leg.br/legin/fed/lei/1980-1987/lei-693831-agosto-1981-366135-publicacaooriginal-1-pl.html, accessed in August 2019.

7. http://www.forumclima.pr.gov.br/arquivos/File/Rosana/ Diagnostico_Qualidade_do_Ar_Versao_Final_Std.pdf, accessed in August 2019.
8. http://www2.mma.gov.br/port/conama/legiabre. cfm?codlegi=740, accessed in August 2019.

9. http://apps.who.int/iris/bitstream/handle/10665/69477/ WHO_SDE_PHE_OEH_06.02_eng.pdf? sequence=1, accessed in August 2019.

10. Tsuruta, F.; de Carvalho, N. J.; da Silva, C. M.; Arbilla, G.; J. Braz. Chem. Soc. 2018, 29, 1291.

11. http://www.euro.who.int/_data/assets/pdf_file/0013/301720/ Evidence-future-update-AQGs-mtg-report-Bonn-sept-oct-15. pdf, accessed in August 2019.

12. https://cetesb.sp.gov.br/ar/padroes-de-qualidade-do-ar/, accessed in August 2019.

13. http://jeap.rio.rj.gov.br/je-metinfosmac/institucional/docs/ entenda_iqa.pdf, accessed in August 2019.

14. http://www.inea.rj.gov.br/cs/groups/public/@inter_dimfis_gear/ documents/document/zwew/mtmx/ edisp/inea0131852.pdf, accessed in August 2019.

15. https://www.R-project.org/, accessed in August 2019.

16. https://www.epa.gov/criteria-air-pollutants/naaqs-table, accessed in August 2019.

17. https://www.arb.ca.gov/research/aaqs/caaqs/caaqs.htm, accessed in August 2019.

18. https://ww2.arb.ca.gov/resources/ozone-and-health, accessed in August 2019.

19. https://eur-1ex.europa.eu/legal-content/EN/ TXT/?uri=CELEX:32008L0050, accessed in August 2019.

20. https://www.env.go.jp/en/air/aq/aq.html, accessed in August 2019.

21. http://www.environment.gov.au/protection/publications/ factsheet-national-standards-criteria-air-pollutants-australia, accessed in August 2019.

22. https://www.data.jma.go.jp/ghg/kanshi/ghgp/o3_e.html, accessed in August 2019.

23. http://www.proam.org.br/noticia.asp?ID=236, accessed in August 2019.

24. Dai, X.; He, X.; Zhou, Z.; Chen, J.; Wei, S.; Chen, R.; Yang, B.; Feng, W.; Shan, A.; Wu, T.; Guo, H.; Int. J. Cardiol. 2015, 192, 56.

25. Pascal, M.; Vérène, W.; Chatignoux, E.; Falq, G.; Corso, M.; Blanchard, M.; Host, S.; Larrieu, S.; Pascal, L.; Declercq, C.; Atmos. Environ. 2012, 62, 6.

26. https://cetesb.sp.gov.br/ar/wp-content/uploads/ sites/28/2019/05/Relat\%C3\%B3rio-de-Qualidade-do-Ar-2017. pdf, accessed in August 2019.

27. https://aqicn.org/map/world/, accessed in August 2019.

28. https://cetesb.sp.gov.br/ar/configuracao-da-rede-automatica/, accessed in August 2019.

29. https://cetesb.sp.gov.br/ar/qualar/, accessed in August 2019.

30. http://www.inea.rj.gov.br/ar-agua-e-solo/monitoramento-daqualidade-do-ar-e-meteorologia/, accessed in August 2019.

31. http://www.rio.rj.gov.br/web/smac/monitorar-rio1, accessed in August 2019. 
32. http://www.inema.ba.gov.br/servicos/monitoramento/ qualidade-do-ar-direciona-para-a-pagina-da-cetrel/, accessed in August 2019.

33. http://www.fepam.rs.gov.br/qualidade/monitor_ar.asp, accessed in August 2019.

34. http://www.feam.br/qualidade-do-ar, accessed in August 2019.

35. https://iema.es.gov.br/qualidadedoar/historico, accessed in August 2019.

36. http://www.iap.pr.gov.br/modules/conteudo/conteudo. php?conteudo=92, accessed in August 2019.

37. http://www.ibram.df.gov.br/programa-de-monitoramento-daqualidade-do-ar-do-df/, accessed in August 2019.

38. https://wribrasil.org.br/pt/blog/2018/06/qualidade-do-ar-nobrasil-o-que-esta-em-jogo-na-mudanca-dos-padroes, accessed in August 2019.
39. http://www.mpf.mp.br/pgr/documentos/PedidoDrAndre_ Padres_Qualidade_Ar.pdf, accessed in August 2019.

40. Lelieveld, J.; Klingmüller, K.; Pozzer, A.; Pöschl, U.; Fnais, M.; Daiber, A.; Münzel, T.; Eur. Heart J. 2019, 40, 1590.

41. https://eur-lex.europa.eu/legal-content/en / ALL/?uri=CELEX:32000L0069, accessed in August 2019.

42. Silva, D. B. N.; Martins, E. M.; Correa, S. M.; Environ. Monit. Assess. 2016, 188, 289.

43. Siqueira, C. Y. S.; Lemos, M. V. P.; Araujo, B. C. C.; Oliveira, R. R. P. E.; Gil, R. A. S. S.; Neto, F. R. A.; Microchem. J. 2017, 133,638 .

44. da Silva, C. M.; da Silva, L. L.; Corrêa, S. M.; Arbilla, G.; Atmos. Pollut. Res. 2018, 9, 369.

Submitted: March 12, 2019

Published online: September 3, 2019 